\title{
Changes in gas permeability and pore structure of wood under heat treating temperature conditions
}

\author{
Eun-Suk Jang ${ }^{1}$ and Chun-Won Kang ${ }^{2^{*}}$
}

\begin{abstract}
In this study, changes in gas permeability and pore structure of wood are evaluated after heat treatment with temperatures ranging from 190 to $230^{\circ} \mathrm{C}$ for $6 \mathrm{~h}$ for both hardwood (yellow poplar: Liriodendron tulipifera) and softwood (Korean red pine: Pinus densiflora). The purpose of this study is to investigate changes in pore size, content of three pore types (through pore, blind pore, and closed pore), as defined by IUPAC, and gas permeability by increasing heat treatment temperatures in hardwood and softwood using capillary flow porometry and gas pycnometry. As the heat treatment temperature increased, only through pore porosity increased, causing an increase in gas permeability.
\end{abstract}

Keywords: Heat-treated wood, Through pore, Blind pore, Closed pore, Capillary flow porometry, Gas pycnometry, Yellow poplar, Korean red pine

\section{Introduction}

Wood is a non-homogeneous hygroscopic material and swells or shrinks due to changes in the equilibrium moisture conditions. Additionally, its hygroscopicity causes poor durability, poor heat resistance, and easy decay [1].

Heat treatment is a method for improving the quality of wood to overcome these demerits. It is generally recognized as an environmentally friendly method because it uses only high temperature or steam without chemical additives [2].

Due to high-temperature heat treatment, the properties of wood are changed as follows: increase in the durability against decay, decrease in hygroscopicity due to a decrease in hydrophilic $\mathrm{OH}$ groups, decrease in the equilibrium moisture content, increase in the dimensional stability, relief of the internal stress, change in the coloration, and decrease in the thermal conductivity [2-6].

In addition, there are many studies on the permeability of wood improvement by heat treatment.

\footnotetext{
*Correspondence: kcwon@jbnu.ac.kr

${ }^{2}$ Department of Housing Environmental Design, and Research Institute of Human Ecology, College of Human Ecology, Chonbuk National University, Jeonju 54896, Korea

Full list of author information is available at the end of the article
}

Yuan [7] reported that the gas permeability of heattreated Eucalyptus was remarkably improved, and the best results were obtained when it was treated at $140{ }^{\circ} \mathrm{C}$ for $5 \mathrm{~h}$.

Taghiyari and Malek [8] reported that heat treatment affected gas permeability. At temperatures below $60{ }^{\circ} \mathrm{C}$, permeability increased due to bound water reduction and shrinkage. Permeability increased due to structural modifications and chemical changes in cell wall components at temperatures above $75^{\circ} \mathrm{C}$.

Kang et al. [2] reported that gas permeability increased after the heat treatment of malas (Homalium foetidum) at $190{ }^{\circ} \mathrm{C}$ for $3 \mathrm{~h}$. Also, they reported increased sound absorption coefficient of malas in longitudinal direction by heat treatment.

In recent years, there are many studies with a special focus on the effects of heat treatment on air permeability and the effects of nano-materials (such as nanosilver, zinc-oxide nanoparticles, nanocopper) on heat treatment of solid wood species. Heat treatment of wood and impregnation of nano-materials such as zinc oxide significantly inhibit growth of the fungus and consequently reduce wood loss. Thus, wood impregnated with nanoparticles improves biological resistance [9-12]. 
Nanoparticles also improve the thermal conductivity of solid wood $[12,13]$.

The purpose of this study is to estimate the relationships between pore characteristics and gas permeability changes caused by heat treatment. This study analyzes the changes in the Darcy permeability constant, pore size, and pore structure defined by IUPAC [14] (through pore, blind pore, closed pore) depending on heat treatment temperature conditions using yellow poplar (hardwood) and Korean red pine (softwood).

\section{Materials and methods}

\section{Specimen preparation}

Logs from 20-year-old yellow poplar trees (Liriodendron tulipifera) grown in Chodanglim Gangjin-gun Jeollanamdo, Republic of Korea, and 20-year-old Korean pine trees (Pinus densiflora) grown in Changseong Jeollanam-do, Republic of Korea, were cut into lumber with the dimensions of $120 \mathrm{~mm}$ for width, $30 \mathrm{~mm}$ for thickness, and $1800 \mathrm{~mm}$ for length.

The lumber was heat treated at 190,210 , and $230{ }^{\circ} \mathrm{C}$ for $6 \mathrm{~h}$ using a high-temperature hot air dryer (model: BPH-9200A, Korea) at Chungnam National University. The control group was not subjected to heat treatment $\left(20^{\circ} \mathrm{C}\right)$.

The lumber was processed into several groups of samples. Each group contained five samples, which had a thickness of $10 \mathrm{~mm}$ and a diameter of $29 \mathrm{~mm}$, as shown in Fig. 1.

To measure true density, these sample specimens were pulverized into wood sawdust, which was sieved by a sifter with a 200 mesh.

\section{Morphology observation for pore cross section of wood using SEM}

To observe the pore morphology of the cross section of wood, specimens were cut into samples with dimension of approximately $5 \times 5 \mathrm{~mm}$, and the surfaces of the sample were smoothly cut using a microtome (model: HM400S, Microm GmbH, Germany). They were coated with gold ions using an ion sputtering apparatus and observed at an acceleration voltage of $10 \mathrm{kV}$ and 400 magnification using a scanning electron microscope (SEM, model: Genesis-1000, Emcrafts, Korea).

\section{Measurement of bulk density and moisture content}

The bulk density and moisture content of the cylindrical specimens were measured according to KS F 2198 [15] and KS F 2199 [16].

\section{Measurement of true density}

The true density and porosity of the heat-treated wood were measured using a gas pycnometer (model: PYC100A-1, Porous Material Inc., USA) following the gas displacement principle according to ASTM C604 [17], D2638 [18], and D4892 [19]. Specifically, the true density and porosity of the cylindrical specimens and the sawdust of each heat treatment temperature condition were measured.

\section{Measurement of gas permeability}

Gas permeability was measured using a capillary flow porometer (model: CFP-1200AEL, Porous Materials, Inc., USA). To minimize the permeability variation due to the air leakage between the curved surface of the cylindrical specimen and sample chamber, the side surface of

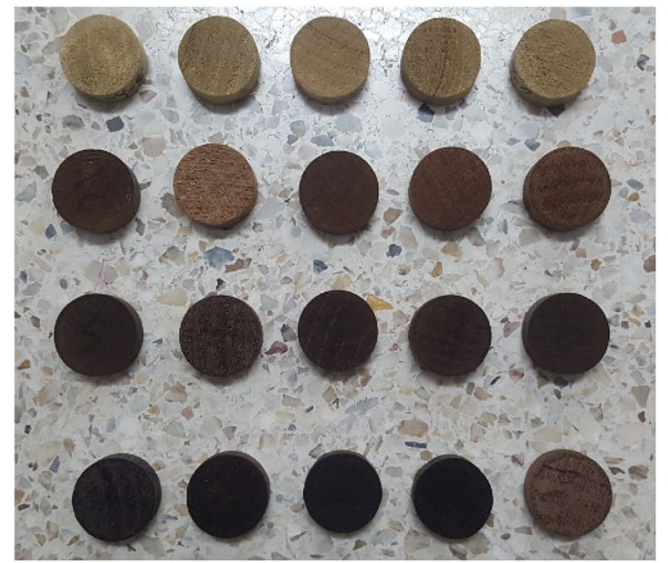

a yellow poplar

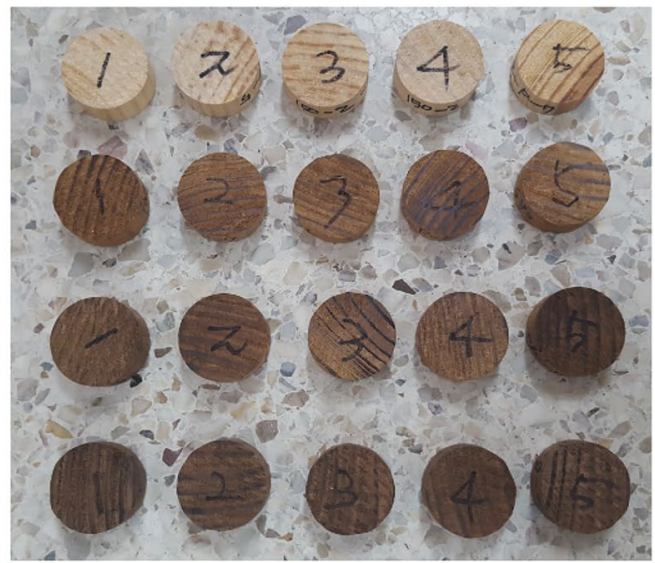

b Korean red pine

Fig. 1 Preparation of yellow poplar and Korean red pine specimens. From top to bottom, the rows denote the (control $\left.\approx 20^{\circ} \mathrm{C}\right)$ and heat treatment at 190,210 , and $230^{\circ} \mathrm{C}$, respectively 
the specimens was sealed with an O-ring and the pressure was increased in the vertical direction. The vertical flow rate was measured by a pressure increase and converted to the Darcy permeability constant according to Darcy's law [20].

Alternatively, the flow through the wood can be modeled as capillary flow in the method by Siau [21], in which case Poiseuille's law is applied.

$$
Q=\left(N \pi r^{2} \Delta p\right) /(8 \eta L)
$$

where $Q=$ rate of flow $(\mathrm{m} / \mathrm{s}) ; N=$ number of capillaries (number); $r=$ capillary radius $(\mathrm{m}) ; p=$ differential pressure $\left(\mathrm{N} / \mathrm{m}^{2}\right) ; \eta=$ viscosity of the fluid $\left(\mathrm{N} \mathrm{s} / \mathrm{m}^{2}\right) ; L=$ distance between the opposing surfaces $(\mathrm{m})$.

\section{Measurement of throat pore diameter of through pores}

The pore size was measured using a capillary flow porometer (model: CFP-1200AEL, Porous Materials, Inc., USA) according to the ASTM F316 [22] test method.

After measuring the gas permeability to detect the flow rate according to pressure, the same samples were wetted sufficiently in low surface tension and low volatility Galwick solution (surface tension $0.0159 \mathrm{~N} / \mathrm{m}$ ) to penetrate into the pores and increase the pressure. At this time, the initial flow rate and increase in flow rate by pressure increase were measured.

The pressure at which the Galwick solution was extruded by air pressure was measured sequentially, and the pore size was determined according to the Washburn equation. The measured pores had the constricted pore diameter of through pores, as shown in Fig. 2.

$$
D=\frac{4 \gamma \cos \theta}{p}
$$

where $D$ : diameter of the pore assuming it is cylindrical (m); $p$ : differential pressure $\left(\mathrm{N} / \mathrm{m}^{2}\right) ; \gamma$ : surface tension of

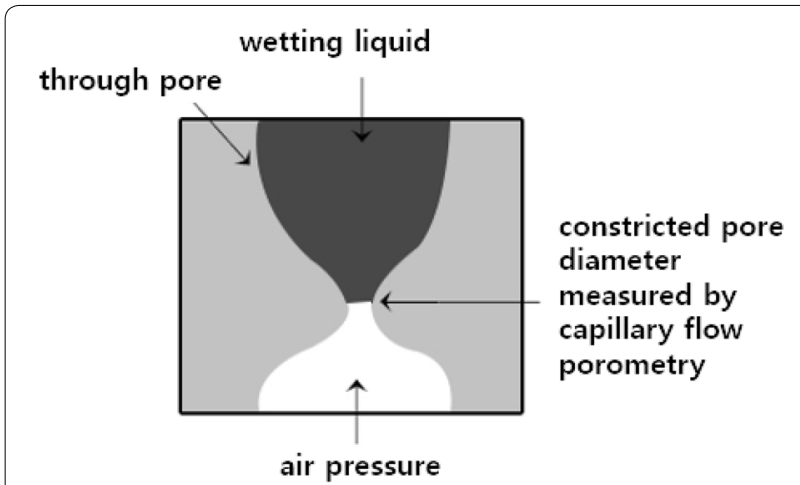

Fig. 2 Illustration of constricted pore diameter measured by capillary flow porometry wetting liquid $(\mathrm{N} / \mathrm{m}) ; \theta$ : contact angle of wetting liquid $\left({ }^{\circ}\right)$.

\section{Porosity measurement of three types of pores (through pore, blind pore, closed pore)}

Jang et al. [23] reported that the pore types of wood can be classified as through pores, blind pores, and closed pores, and their contents were determined. In this study, the same method was used.

Total porosity $\phi_{\text {total }}(\%)$ can be calculated using true volume $\left(V_{\text {true }}\right)$ of the sawdust as measured by gas pycnometer and bulk volume $\left(V_{\text {bulk }}\right)$ of the cylindrical specimen according to the dimension method [14]

$$
\phi_{\text {total }}(\%)=\left(1-\frac{V_{\text {true }}}{V_{\text {bulk }}}\right) \times 100
$$

The volume of pores in the cylindrical specimen as measured by a gas pycnometer is the sum of through pore volume $\left(V_{\text {through }}\right)$ and blind pore volume $\left(V_{\text {blind }}\right)$. From these results, the sum of through pore porosity $\left(\phi_{\text {through }}\right)$ and blind pore porosity $\left(\phi_{\text {blind }}\right)$ can be obtained

$$
\phi_{\text {through }}+\phi_{\text {blind }}=\frac{V_{\text {through }}+V_{\text {blind }}}{V_{\text {bulk }}} \times 100
$$

The closed pore porosity $\left(\phi_{\text {closed }}\right)$ is calculated from Eqs. (3) and (4)

$$
\phi_{\text {closed }}=\phi_{\text {total }}-\phi_{\text {through }}+\phi_{\text {blind }}
$$

To separate blind pore porosity $\left(\phi_{\text {blind }}\right)$ and through pore porosity $\left(\phi_{\text {through }}\right)$, the cylindrical specimens were steeped in Galwick (surface tension $0.0159 \mathrm{~N} / \mathrm{m}$ ), and the liquid was intruded into the pores using a vacuum pump.

Then, the specimens were placed in a chamber, both sides of which were sealed with O-rings, and air pressure was applied in the vertical direction.

As the air pressure was increased, only Galwick in the through pores was extruded. The liquid inside blind pores could not be extruded because blind pores were blocked at one end.

The mass of Galwick in blind pores was calculated as the difference in specimen mass after extrusion $\left(M_{\text {after extrusion }}\right)$ and dried specimen mass $\left(M_{\text {dried }}\right)$. Finally, the blind pore volume $\left(V_{\text {blind }}\right)$ was calculated using the difference in specimen mass $\left(M_{\text {after extrusion }}-M_{\text {dried }}\right)$ and specific gravity of Galwick $\left(\rho_{\text {Galwick }}\right)$

$$
\begin{aligned}
& V_{\text {blind }}=\frac{M_{\text {after extrusion }}-M_{\text {dried }}}{\rho_{\text {Galwick }}} \\
& \phi_{\text {blind }}=\frac{V_{\text {blind }}}{V_{\text {bulk }}} \times 100 \\
& \phi_{\text {through }}=\left(\phi_{\text {through }}+\phi_{\text {blind }}\right)-\phi_{\text {blind }}
\end{aligned}
$$


Hence, according to the above equation, the through pore porosity $\left(\phi_{\text {through }}\right)$, blind pore porosity $\left(\phi_{\text {blind }}\right)$, and closed pore porosity $\left(\phi_{\text {closed }}\right)$ of the heat-treated cylindrical specimens are calculated.

\section{Results and discussion}

Results of morphology observation

As the heat treatment temperature increases, the pore morphology of the cross section changes, as shown in Figs. 3 and 4 .

In this study, it was difficult to determine the difference of anatomical features in the surface pore morphology of the cross section by heat treatment in yellow poplar, similar to the findings in Kim et al. [24].

In contrast, in Korean red pine, the earlywood tracheid cell walls thinned in the heat-treated samples at $210{ }^{\circ} \mathrm{C}$ and $230{ }^{\circ} \mathrm{C}$. The pore size and porosity may increase after the heat treatment.
Results of bulk density and moisture content (MC)

The bulk density and MC of the heat-treated wood specimens are shown in Figs. 5 and 6.

The average bulk density of yellow poplar decreased from $0.42 \mathrm{~g} / \mathrm{cm}^{3}$ of control (standard deviation $\mathrm{SD}=0.03$ ) to $0.38 \mathrm{~g} / \mathrm{cm}^{3}(\mathrm{SD}=0.02), 0.36 \mathrm{~g} / \mathrm{cm}^{3}(\mathrm{SD}=0.01)$, and $0.35 \mathrm{~g} / \mathrm{cm}^{3}(\mathrm{SD}=0.03)$ as the temperature increased to $190{ }^{\circ} \mathrm{C}, 210{ }^{\circ} \mathrm{C}$, and $230{ }^{\circ} \mathrm{C}$, respectively. The deviation from untreated (control) specimens to that of specimens treated at $230{ }^{\circ} \mathrm{C}$ was $16.46 \%$.

The average bulk density of Korean red pine decreased from $0.52 \mathrm{~g} / \mathrm{cm}^{3}$ of control $(\mathrm{SD}=0.03)$ to $0.51 \mathrm{~g} / \mathrm{cm}^{3}$ $(\mathrm{SD}=0.06), \quad 0.50 \mathrm{~g} / \mathrm{cm}^{3} \quad(\mathrm{SD}=0.06)$, and $0.44 \mathrm{~g} / \mathrm{cm}^{3}$ $(\mathrm{SD}=0.02)$ as the temperature increased to 190,210 , and $230{ }^{\circ} \mathrm{C}$, respectively, and the deviation from untreated (control) specimens to that of specimens treated at $230{ }^{\circ} \mathrm{C}$ was $14.14 \%$.

In the previous studies, Zaman et al. [25] reported that after heat treating Pine (Pinus sylvestris) and Birch

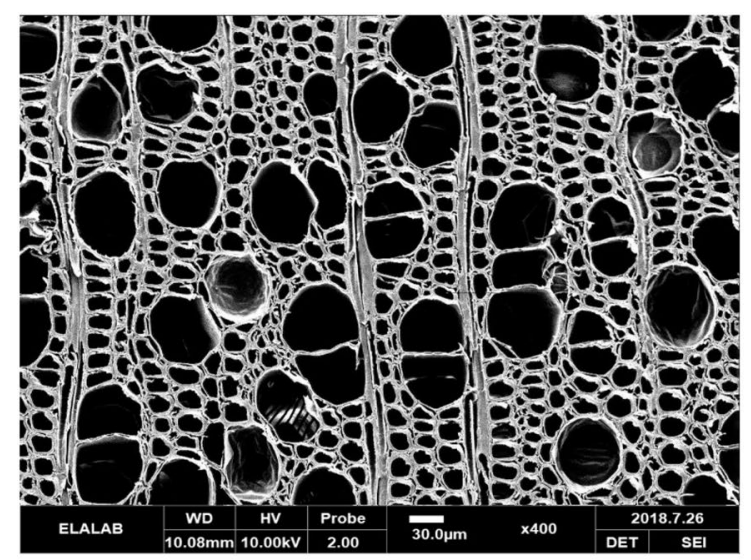

a control

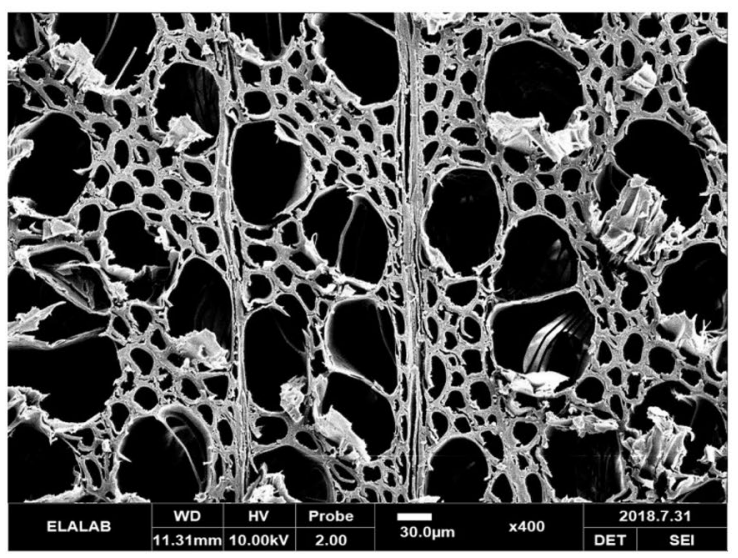

c $210^{\circ} \mathrm{C}$

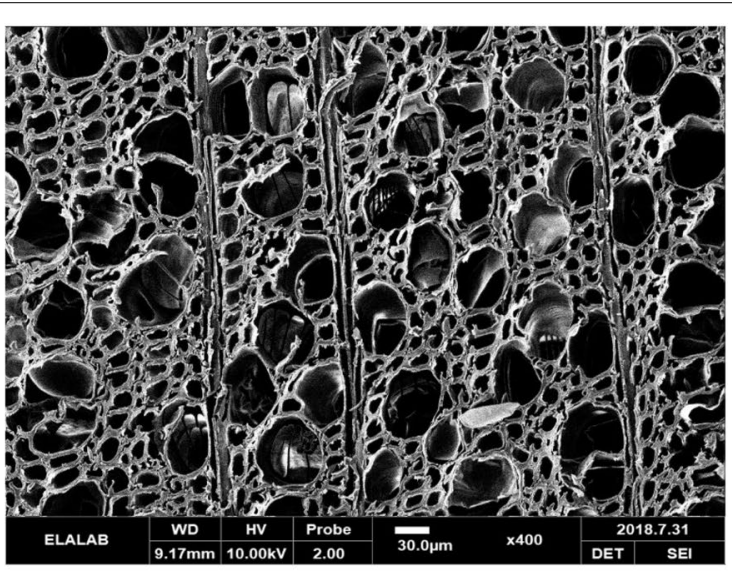

b $190{ }^{\circ} \mathrm{C}$

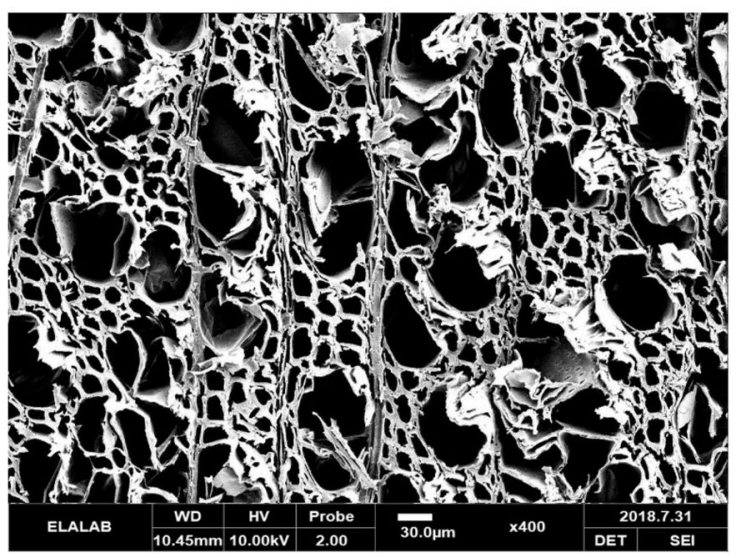

d $230^{\circ} \mathrm{C}$

Fig. 3 Typical SEM observations on the cross section of yellow poplar according to the heat treating temperature 


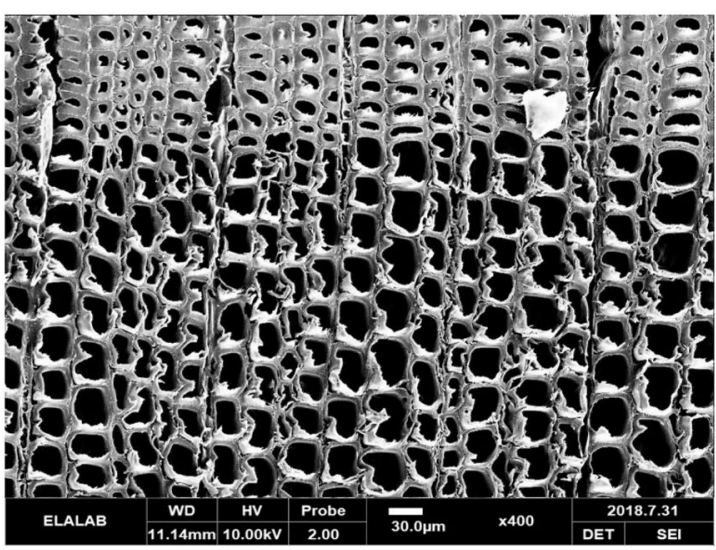

a control

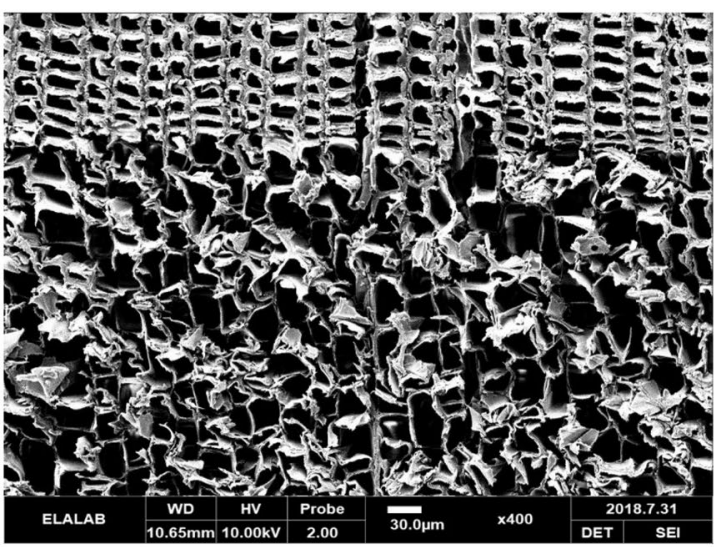

c $210^{\circ} \mathrm{C}$

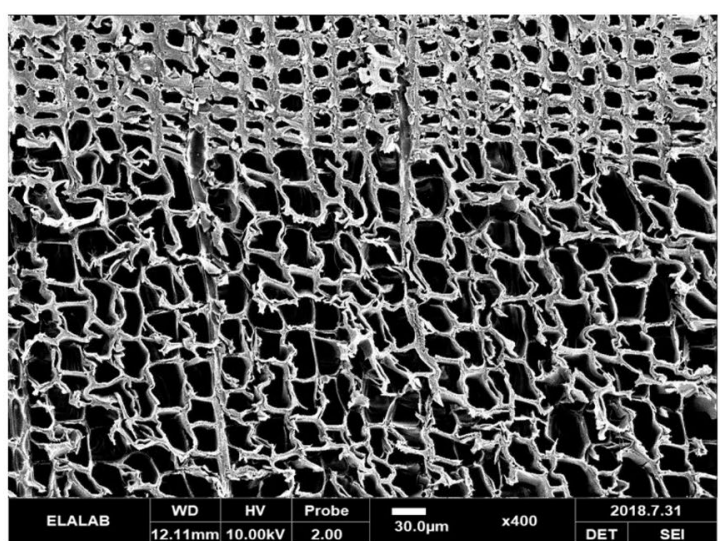

b $190^{\circ} \mathrm{C}$

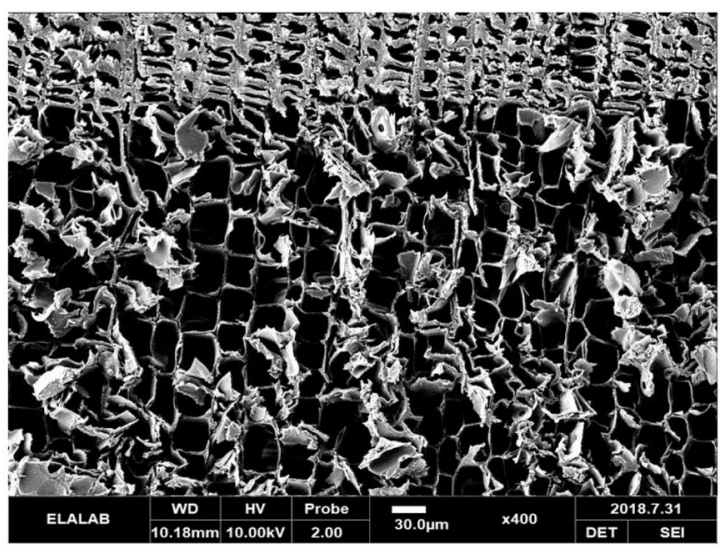

d $230^{\circ} \mathrm{C}$

Fig. 4 Typical SEM observations on the cross section of Korean red pine according to the heat treating temperature

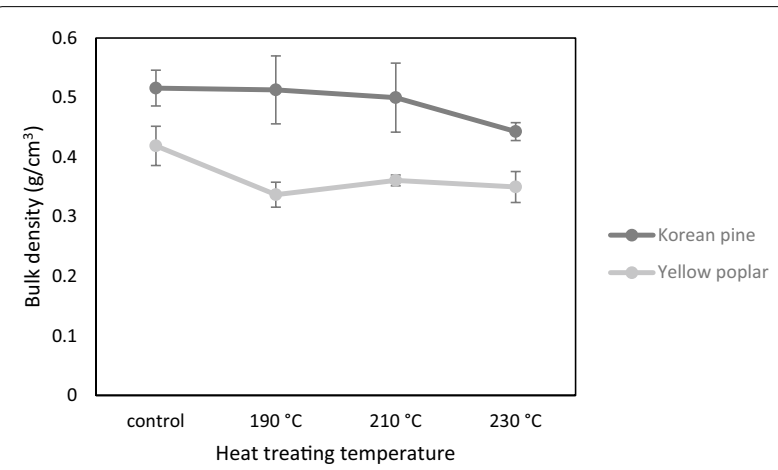

Fig. 5 Bulk density of Korean red pine and yellow poplar according to the heat treating temperature (error bar standard deviation)

(Betula pendula), the mass loss of Birch was more than that of Pine.

Easteve et al. [26] reported that Eucalyptus (Eucalyptus globulus) exhibited a greater mass loss than

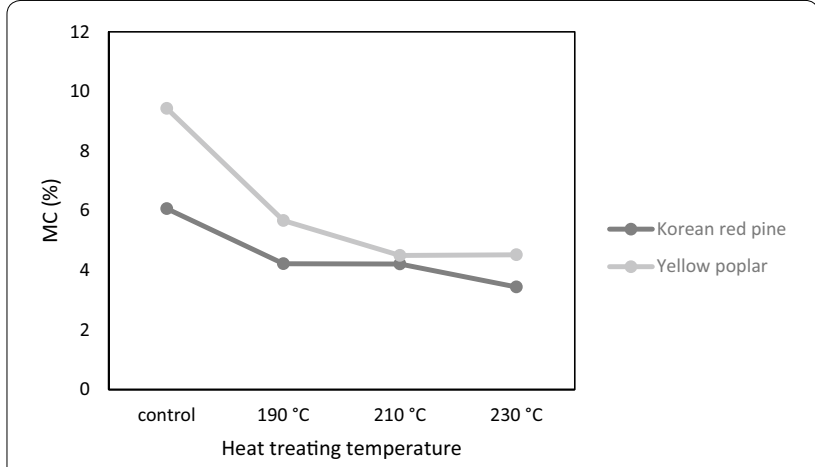

Fig. 6 MC of Korean red pine and yellow poplar according to the heat treating temperature

Pine (Pinus pinaster) under the same heat treatment conditions.

The MC of the yellow poplar was decreased from $6.07 \%$ (control) to $4.22,4.21$ and $3.44 \%$ as the heat 
treating temperature increased to 190,210 and $230{ }^{\circ} \mathrm{C}$, respectively.

The MC of Korean red pine decreased from 9.43\% (control) to 5.67, 4.50, and $4.52 \%$ as the heat treating temperature increased to 190,210 and $230{ }^{\circ} \mathrm{C}$, respectively. These results are attributed to the decrease in moisture content after high-temperature heat treatment.

For this reason, Jämsä and Vittaniemi [27] reported that the hygroscopicity by cell walls is reduced as the wood chemistry changes due to the decrease in the hydroxyl groups after heat treatment. It is also reported that water molecules are inaccessible to hydroxyl groups due to an increase in cellulose crystallinity [28-30].

\section{Results of true density}

The true density of the cylindrical specimens and the sawdust of each heat-treated wood specimen is shown in Figs. 7 and 8.

The true densities of the yellow poplar cylindrical specimens were $1.23(\mathrm{SD}=0.02), 1.19(\mathrm{SD}=0.09), 1.22$ $(\mathrm{SD}=0.04)$, and $1.20 \mathrm{~g} / \mathrm{cm}^{3}(\mathrm{SD}=0.05)$ for the control and with heat treating at 190,210 and $230{ }^{\circ} \mathrm{C}$, respectively. There were no significant differences according to

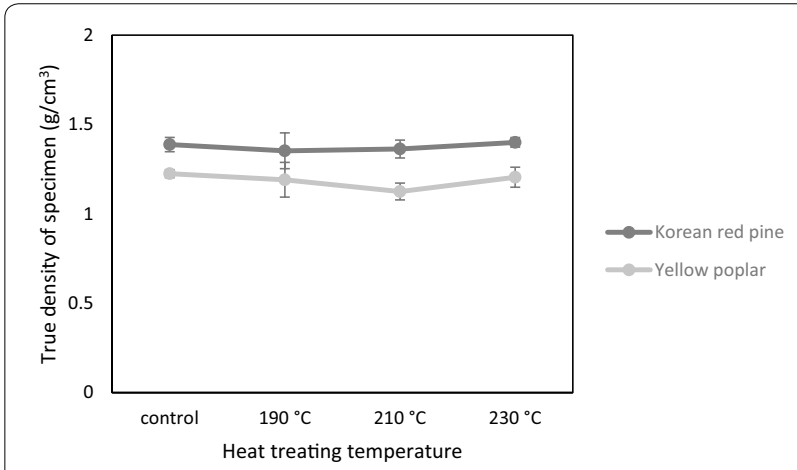

Fig. 7 True density of specimens of Korean red pine and yellow poplar according to the heat treating temperature (error bar standard deviation)

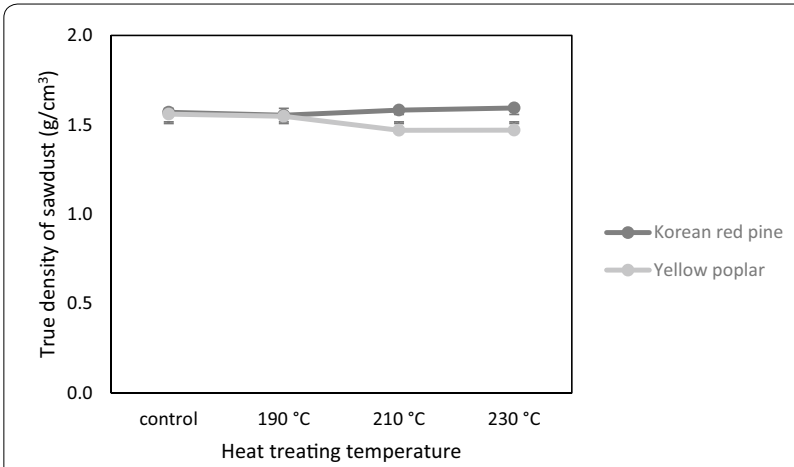

Fig. 8 True density of sawdust of Korean red pine and yellow poplar according to the heat treating temperature the heat treating temperature. The true density of a cylindrical specimen measured by a gas pycnometer assumes the sample has no interior closed pores [14].

In contrast, the true densities of the sawdust samples were $1.56(\mathrm{SD}=0.01), 1.55(\mathrm{SD}=0.03), 1.47(\mathrm{SD}=0.02)$, and $1.47 \mathrm{~g} / \mathrm{cm}^{3}(\mathrm{SD}=0.04)$ for the control and with heat treating at 190,210 , and $230{ }^{\circ} \mathrm{C}$, respectively. As the heat treating temperature increases, the true density of the sawdust decreases.

As the wood is heat treated at over $160{ }^{\circ} \mathrm{C}$, thermal hydrolysis occurs. In response, hemicellulose, having a high hydrophilicity, is decomposed first and then cellulose and lignin are deformed [31]. For this reason, it seems that as the heat treating temperature increases, the true density of the sawdust of yellow poplar decreases.

The true densities of the Korean red pine cylindrical specimens were $1.39(\mathrm{SD}=0.04), 1.35(\mathrm{SD}=0.10)$, $1.36(\mathrm{SD}=0.05)$, and $1.40 \mathrm{~g} / \mathrm{cm}^{3}(\mathrm{SD}=0.02)$ for the control and with heat treating at 190,210 , and $230{ }^{\circ} \mathrm{C}$, respectively. Similar to the yellow poplar, there was no significant difference according to the heat treating temperature. The true density of the sawdust was 1.57 $(\mathrm{SD}=0.01), 1.55(\mathrm{SD}=0.01) 1.58(\mathrm{SD}=0.01)$, and $1.59 \mathrm{~g} /$ $\mathrm{cm}^{3}(\mathrm{SD}=0.02)$ for the control and with heat treating at 190,210 and $230{ }^{\circ} \mathrm{C}$, respectively. As the heat treating temperature increased, the true density tended to increase.

In Korean red pine, the tendency of the true density change in relation to the increase in heat treating temperature was different from yellow poplar. It seems that these results were attributed to the composition ratio variance of hemicellulose in softwood and hardwood, and the thermal degradation of hardwood xylans is greater than that of softwood mannans [32].

\section{Results of gas permeability}

The values of the Darcy permeability constant and the mean values at each heat treating temperature for the samples are shown in Fig. 9.

The Darcy permeability of the yellow poplar was increased from $0.09(\mathrm{SD}=0.04)$ to $0.14(\mathrm{SD}=0.08), 0.18$ $(\mathrm{SD}=0.09)$, and $0.28(\mathrm{SD}=0.09)$ as the heat treating temperature increased from the control to 190, 210, and $230{ }^{\circ} \mathrm{C}$, respectively. After heat treatment, the gas permeability was 3.1 times higher than that of the untreated sample (control).

The Darcy permeability constant of Korean red pine was increased from $0.42(\mathrm{SD}=0.09)$ to $0.59(\mathrm{SD}=0.20)$, $0.69(\mathrm{SD}=0.10)$, and $0.77(\mathrm{SD}=0.10)$ as the heat treating temperature increased from the control to 190, 210 , and $230{ }^{\circ} \mathrm{C}$, respectively. After heat treatment, the 


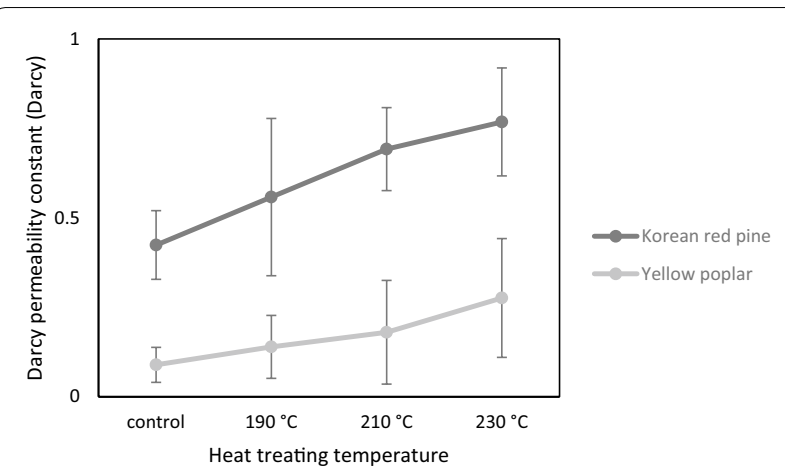

Fig. 9 Darcy permeability constant of Korean red pine and yellow poplar according to the heat treating temperature (error bar standard deviation) gas permeability was 1.81 times higher than that of the untreated sample (control).

These results agree with those of the previous studies $[25,26]$ showing that the increase in mass loss after heat treatment is greater in hardwood than in softwood.

Moreover, Chang et al. [33] reported that micro-pore expansion in cell walls due to volatilization of the extract was observed during heat the treatment.

The mass loss might increase the amount of through pores in the wood by heat treatment. As a result, yellow poplar has higher gas permeability than Korean red pine after the heat treatment.

In the case of the Korean red pine specimens in this study, gas permeability was greater than the general extent of other red pine species, although there were no apparent cracks in the specimens. There are empty resin canals due to resin extraction by wood drying caused by a higher fluid current and increased gas permeability.

\section{Results of through pore diameter}

The maximum pore size and the mean pore size of through pores measured by the capillary flow porometry and the average value of each part are presented in Figs. 10 and 11.

The maximum pore size of yellow popular was increased from $13.67(\mathrm{SD}=13.80)$ to $14.54(\mathrm{SD}=10.67)$, $18.45(\mathrm{SD}=12.11)$, and $22.77 \mu \mathrm{m}(\mathrm{SD}=2.66)$ as the heat treating temperature increased from the control to $190{ }^{\circ} \mathrm{C}, 210{ }^{\circ} \mathrm{C}$, and $230{ }^{\circ} \mathrm{C}$, respectively, and the mean pore size was also increased from $0.98(\mathrm{SD}=1.24)$ to 0.59 $(\mathrm{SD}=0.43), 1.08(\mathrm{SD}=1.15)$, and $1.32 \mu \mathrm{m}(\mathrm{SD}=1.37)$ as the heat treating temperature increased from the control to 190,210 and $230{ }^{\circ} \mathrm{C}$, respectively.

The maximum pore size of Korean red pine was increased from $20.50(\mathrm{SD}=3.09)$ to $27.01(\mathrm{SD}=10.78)$,

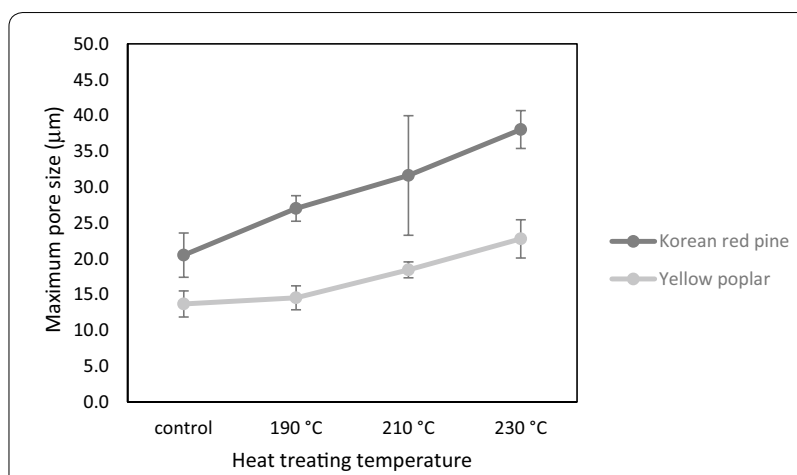

Fig. 10 Maximum pore size of Korean red pine and yellow poplar according to the heat treating temperature (error bar standard deviation)

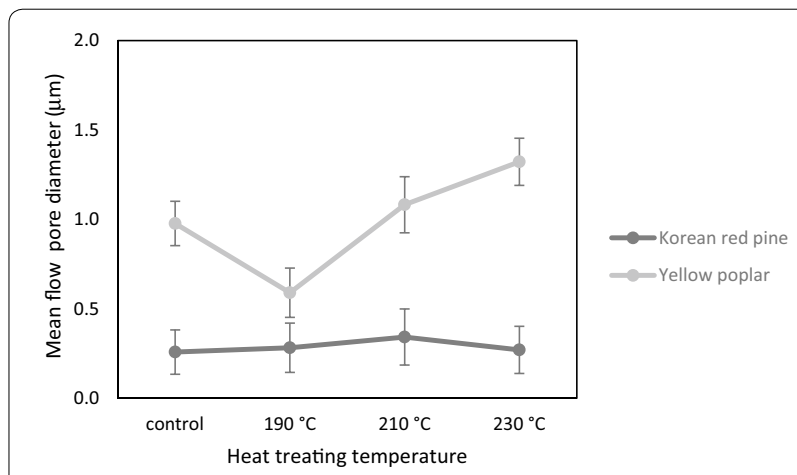

Fig. 11 Mean flow pore diameter of Korean red pine and yellow poplar according to the heat treating temperature (error bar standard deviation)

31.64 $(\mathrm{SD}=8.38)$, and $38.04 \mu \mathrm{m}(\mathrm{SD}=2.64)$ as the heat treating temperature increased from the control to 190, 210 , and $230{ }^{\circ} \mathrm{C}$, respectively, and mean pore size was also increased from $0.26(\mathrm{SD}=0.03)$ to $0.28(\mathrm{SD}=0.22)$, $0.34(\mathrm{SD}=0.13)$, and $0.27 \mu \mathrm{m}(\mathrm{SD}=0.01)$ as the heat treating temperature increased from the control to 190 , 210 and $230{ }^{\circ} \mathrm{C}$, respectively.

From this study, the increase in pore size was caused by the degradation of wood components by heat treatment, and expansion of micro-pores in the cell wall, and the increase in gas permeability.

\section{Results of the three types of porosity (through pore, blind pore, closed pore)}

The pore types of heat-treated wood were classified as through pore, blind pore, and closed pore by the IUPAC definition [14] using gas pycnometry and capillary flow porometry. The amount of each pore type is shown in Figs. 12 and 13. 


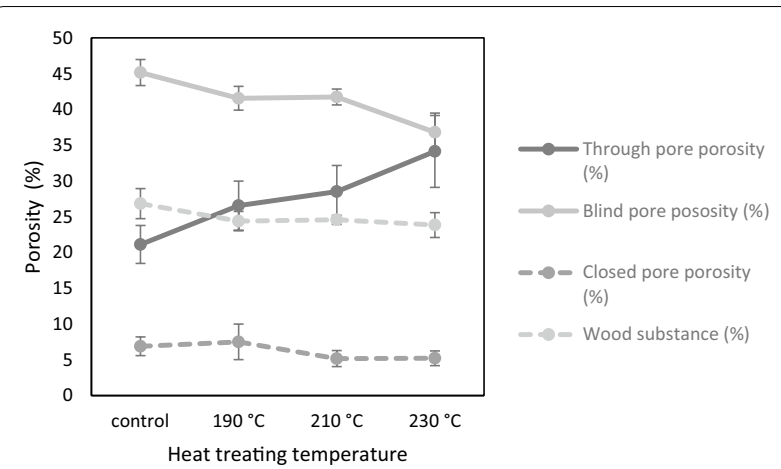

Fig. 12 Porosity analysis of heat-treated yellow poplar specimens (error bar standard deviation)

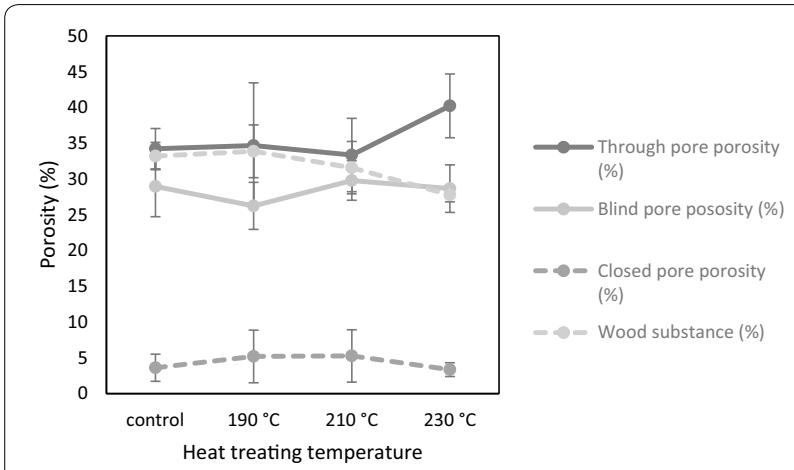

Fig. 13 Porosity analysis of heat-treated Korean red pine specimens (error bar standard deviation)

The total porosity of yellow popular was increased from $73.17(\mathrm{SD}=2.09)$ to $75.62(\mathrm{SD}=1.35), 75.43(\mathrm{SD}=0.63)$, and $76.16 \%(\mathrm{SD}=1.74)$ as the heat treating temperature increased from the control to 190,210 , and $230{ }^{\circ} \mathrm{C}$, respectively.

The through pore porosity increased from 21.12 $(\mathrm{SD}=2.64)$ to $26.57 \quad(\mathrm{SD}=3.42), 28.52 \quad(\mathrm{SD}=3.64)$, and $34.13 \%(\mathrm{SD}=5.02)$ as the heat treating temperature increased from the control to 190,210 , and $230{ }^{\circ} \mathrm{C}$, respectively. Thus, blind pore porosity, closed pore porosity, and wood substance tended to decrease with an increase in through pore porosity.

The total porosity of Korean red pine was increased from $66.79(\mathrm{SD}=1.90)$ to $66.12(\mathrm{SD}=3.68), 68.42$ $(\mathrm{SD}=3.66)$, and $72.23 \%(\mathrm{SD}=0.96)$ as the heat treating temperature increased from the control to 190, 210, and $230{ }^{\circ} \mathrm{C}$, respectively.

The through pore porosity was $34.23(\mathrm{SD}=2.82)$, $34.68(\mathrm{SD}=8.76), \quad 33.35 \quad(\mathrm{SD}=5.12)$, and $40.42 \%$ $(\mathrm{SD}=4.45)$, respectively, and the through pore porosity tended to increase rapidly at $230{ }^{\circ} \mathrm{C}$.
It is considered that the cellulose of Korean red pine was decomposed in the range of $210-220^{\circ} \mathrm{C}$.

\section{Conclusions}

The experimental results of gas permeability and pore structure depending on the heat treating temperature conditions for yellow poplar and Korean red pine are summarized as follows.

1. Based on observations of cross sections of wood after heat treatment using SEM, there is no significant change experienced in yellow poplar.

2. The higher the heat treating temperature, the greater the gas permeability and the increase in pore size in the cross sections of wood. As heat treating temperature increased, the degree of increase in gas permeability of yellow poplar was greater than that of Korean red pine.

3. In yellow poplar, through pore porosity (\%) increased with increasing heat treating temperature. On the contrary, in Korean red pine, the through pore porosity (\%) did not change significantly until $210{ }^{\circ} \mathrm{C}$ and showed a large increase by $230{ }^{\circ} \mathrm{C}$.

The decrease in wood density caused by the increase in heat treatment temperature was attributed to decomposition of cell wall compounds and changes in their chemical compositions. Additionally, it seems that these processes result in expanding the pores in the wood, increasing the through pore porosity (\%) and increasing the gas permeability.

In addition, due to the different chemical changes depending on the heat treating temperature between hardwood (yellow popular) and softwood (Korean red pine), the change rate of mass loss varies, and thus, the variation of pore size, porosity, and gas permeability are different. To clarify these trends, further investigation of the characteristics of yellow poplar and Korean red pine depending on heat treating temperature is needed.

\section{Abbreviations}

$\varphi_{\text {total }}$ : total porosity; $\varphi_{\text {through: }}$ through pore porosity; $\varphi_{\text {blind }}$ : blind pore porosity; $\varphi_{\text {closed: }}$ closed pore porosity; $V_{\text {true }}$ : true volume; $V_{\text {bulk: }}$ : bulk volume; $V_{\text {through: }}$ through pore volume; $V_{\text {blind }}$ : blind pore volume; $M_{\text {after extrusion: }}$ difference in specimen mass after extrusion; $M_{\text {dried }}$ : dried specimen mass; $\rho_{\text {Galwick }}$ : specific gravity of Galwick; MC: moisture contents; SD: standard deviation.

\section{Acknowledgements}

This research was supported by the Basic Science Research Program through the National Research Foundation of Korea (NRF) funded by the Ministry of Science and ICT (NRF-2017R1A2B4012538).

This manuscript is based on a part of the first author's master's thesis from Chonbuk National University. 


\section{Authors' contributions}

ESJ designed this study and examined all the tests, and was a major contributor in writing the manuscript. CWK contributed to analysis of data and contributes to discussion on the obtained results. All authors read and approved the final manuscript.

\section{Funding}

No funding.

\section{Availability of data and materials}

Not applicable.

\section{Competing interests}

The authors declare that they have no competing interests.

\section{Author details}

${ }^{1}$ Department of Housing Environmental Design, College of Human Ecology, Chonbuk National University, Jeonju 54896, South Korea. ${ }^{2}$ Department of Housing Environmental Design, and Research Institute of Human Ecology, College of Human Ecology, Chonbuk National University, Jeonju 54896, Korea.

Received: 27 March 2019 Accepted: 10 July 2019

Published online: 26 July 2019

\section{References}

1. Xie YJ, Liu YX, Sun YX (2002) Heat-treated wood and its development in Europe. J For Res 13(3):224-230

2. Kang CW, Li C, Jang ES, Jang SS, Kang HY (2018) Changes in sound absorption capability and air permeability of Malas (Homalium foetidum) specimens after high temperature heat treatment. J Korean Wood Sci Technol 46(2):149-154

3. Esteves B, Pereira H (2008) Wood modification by heat treatment: a review. BioResources 4(1):370-404

4. Candelier K, Thevenon MF, Petrissans A, Dumarcay S, Gerardin P, Petrissans $M$ (2016) Control of wood thermal treatment and its effects on decay resistance: a review. Ann For Sci 73(3):571-583

5. Kocaefe D, Poncsak S, Boluk Y (2008) Effect of thermal treatment on the chemical composition and mechanical properties of birch and aspen. BioResources 3:517-537

6. Ahmed SA, Sehlstedt-Persson M, Hansson L, Morén T (2013) Evaluation of preservative distribution in thermally modified European aspen and birch boards using computed tomography and scanning electron microscopy. J Wood Sci 59(1):57-66

7. Yuan L (1994) Heat treatment of Eucalyptus wood and its permeability improvement. China Wood Ind 8(3):30-33 (in Chinese)

8. Taghiyari HR, Malek BM (2014) Effect of heat treatment on longitudinal gas and liquid permeability of circular and square-shaped native hardwood specimens. Heat Mass Transf 50(8):1125-1136

9. Ghorbani M, Akhtari M, Taghiyari HR, Kalantari A (2012) Effects of silver and zinc-oxide nanoparticles on gas and liquid permeability of heattreated Paulownia wood. Austrain J For Sci 129(2):106-123

10. Taghiyari HR, Ghorbani M, Kalantari A (2013) Effects of silver and copper nanoparticles on gas and liquid permeability of heat-treated solid woods. Spec Top Rev Porous Media 4(1):81-97

11. Taghiyari HR, Avramidis S (2019) Specific gas permeability of normal and nanosilver-impregnated solid wood species as influenced by heat-treatment. Maderas. Cienc Tecnol 21(1):89-96

12. Taghiyari HR, Kalantari A, Ghorbani M, Bavaneghi F, Akhtari M (2015) Effects of fungal exposure on air and liquid permeability of nanosilverand nanozincoxide-impregnated Paulownia wood. Int Biodeterior Biodegrad 105:51-57

13. Taghiyari HR, Ghorbanali M, Tahir PM (2014) Effects of the improvement in thermal conductivity coefficient by nano-wollastonite on physical and mechanical properties in medium-density fiberboard (MDF). BioResources 9(3):4138-4149

14. Rougquerolt J, Avnir D, Fairbridge CW, Evertt DH, Haynes JH, Pernicone N, Ramsay JDF, Sing KSW, Unger KK (1994) Recommendations for the characterization of porous solids (Technical Report). Pure Appl Chem 66(8):1739-1758

15. KS F 2198 (2016) Determination of density and specific gravity of wood Korean Standard Association, Seoul

16. KS F 2199 (2016) Determination of moisture content of wood. Korean Standard Association, Seoul

17. ASTM C604-02 (2007) Standard test method for true specific gravity of refractory materials by Gas-comparison pycnometry-committee $\mathrm{C} 08$ on refractories. American Society of Testing and Materials, West Conshohocken

18. ASTM D2638-10 (2010) Standard test method for real density of calcined petroleum coke by helium pycnometer-committee D02 on petroleum products and lubricants. American Society of Testing and Materials, West Conshohocken

19. ASTM D4892-14 (2014) Standard test method for density of solid pitch (helium pycnometer method). American Society of Testing and Materials, West Conshohocken

20. Darcy H (1856) Les fontaines publiques de la ville de Dijon. Dalmont, Paris (in French)

21. Siau JF (2012) Transport processes in wood (2). Springer Science \& Business Media, New York

22. ASTM F316-11 (2011) Standard test methods for pore size characteristics of membrane filters by bubble point and mean flow pore test. American Society of Testing and Materials, West Conshohocken

23. Jang ES, Kang CW, Jang SS (2019) Pore characterization in cross section of yellow poplar (Liriodendron tulipifera) wood. J Korean Wood Sci Technol 47(1):8-20

24. Kim KM, Park JH, Park BS, Son DW, Park JS, Kim WS, Kim BN, Shim SR (2010) Physical and mechanical properties of heat-treated domestic yellow poplar. J Korean Wood Sci Technol 38(1):17-26

25. Zaman A, Alén R, Kotilainen R (2007) Thermal behavior of Scots pine (Pinus sylvestris) and silver birch (Betula pendula) at 200-230. Wood Fiber Sci 32(2):138-143

26. Esteves B, Marques AV, Domingos I, Pereira H (2007) Influence of steam heating on the properties of pine (Pinus pinaster) and eucalypt (Eucalyptus globulus) wood. Wood Sci Technol 41(3):193-207

27. Jämsä S. Viitaniemi P (2001) Heat treatment of wood: Better durability without chemicals. In: Rapp AO (ed), Review on heat treatments of wood. Proceedings of the special seminar of cost action E22, Antibes, France, Feb 9

28. Wikberg H, Maunu SL (2004) Characterisation of thermally modified hardand softwoods by 13C CPMAS NMR. Carbohyd Polym 58(4):461-466

29. Bhuiyan TR, Hirai N (2005) Study of crystalline behavior of heat-treated wood cellulose during treatments in water. J Wood Sci 51 (1):42-47

30. Boonstra MJ, Tjeerdsma B (2006) Chemical analysis of heat treated softwoods. Eur J Wood Wood Prod 64(3):204-211

31. Garrote G, Dominguez H, Parajo JC (1999) Hydrothermal processing of lignocellulosic materials. Eur J Wood Wood Prod 57(3):191-202

32. Alén R, Oesch P, Kuoppala E (1995) Py_GC/AED studies on the thermochemical behavior of softwood. J Anal Appl Pyrolysis 35(2):259-265

33. Chang YS, Han YJ, Eom CD, Park JS, Park MJ, Choi IG, Yeo HM (2012) Analysis of factors affecting the hygroscopic performance of thermally treated Pinus koraiensis wood. J Korean Wood Sci Technol 40(1):10-18

\section{Publisher's Note}

Springer Nature remains neutral with regard to jurisdictional claims in published maps and institutional affiliations. 